\title{
Molecular and epidemiological updates on cystic echinococcosis infecting water buffaloes from Egypt
}

\author{
Ibrahim Abbas \\ Department of Parasitology, Faculty of Veterinary Medicine, Mansoura University, Egypt. \\ Corresponding author: Ibrahim Abbas, e-mail: ielsayed@mans.edu.eg \\ Received: 26-07-2016, Accepted: 11-11-2016, Published online: 04-12-2016
}

doi: 10.14202/vetworld.2016.1355-1363 How to cite this article: Abbas I (2016) Molecular and epidemiological updates on cystic echinococcosis infecting water buffaloes from Egypt, Veterinary World, 9(12): 1355-1363.

\begin{abstract}
Aim: Cystic echinococcosis (CE) represents a serious parasitic disease at both animal and public health levels. The majority of reports negated the CE infection in buffaloes from Egypt; however, one study illustrated their infection with G6 genotype (camel strain). The present work contributed to update the epidemiological and molecular knowledge about CE infecting this economically important animal for better understanding of its role in maintaining the Echinococcus life cycle.

Materials and Methods: A total of 120 slaughtered water buffaloes at Mansoura abattoir, Dakahlia province, Egypt, were inspected for the existence of hydatid cysts. Cysts location and fertility were examined. Five out of 27 revealed cysts were tested molecularly using both cytochrome $\mathrm{C}$ oxidase subunit 1 and nicotinamide adenine dinucleotide hydrogen subunit 1 (nadh1) genes.
\end{abstract}

Results: Low prevalence (4.2\%) as well as considerably low fertility rate (14.8\%) of buffaloes CE was noted. G1 genotype (common sheep strain) was revealed from the five examined cysts. At the level of nadh1 partial sequences, a globally singleton G1 haplotype was reported.

Conclusion: This the first report about the G1 infection in buffaloes from Egypt. This study proposed the minimized role of this animal in echinococcosis transmission. These findings could provide preliminary data for the local control of this disease.

Keywords: buffalo, Echinococcus, Egypt, genotype, prevalence.

\section{Introduction}

Cystic echinococcosis (CE) is an important parasitic infection which caused by the larval stages (hydatid cyst) of the genus Echinococcus (a dog tapeworm) [1]. This parasite has a two-host life cycle in which canines serve as definitive hosts, while the intermediate host role is played by the domestic and wild ungulates [2]. Transmission of infection is initiated by ingestion either of Echinococcus eggs by the intermediate host or the larval stage by the definitive host.

CE constitutes a serious animal health concern in many rural areas of the world altogether with its public health hazards. From the economic perspective, CE causes important economic losses originated from decreased productivity and viscera condemnation in livestock species. In Ismailia city abattoir (a small Egyptian abattoir), the estimated annual loss in livestock due to $\mathrm{CE}$ was 36,480 Egyptian pounds which represented by total or partial condemnation of $1216 \mathrm{~kg}$ of meat and offal [3].

Copyright: Ibrahim Abbas. Open Access. This article is distributed under the terms of the Creative Commons Attribution 4.0 International License (http://creativecommons.org/licenses/ by/4.0/), which permits unrestricted use, distribution, and reproduction in any medium, provided you give appropriate credit to the original author(s) and the source, provide a link to the Creative Commons license, and indicate if changes were made. The Creative Commons Public Domain Dedication waiver (http:// creativecommons.org/publicdomain/zero/1.0/) applies to the data made available in this article, unless otherwise stated.
Buffaloes are widely reared in Egypt. Economically, it considered the second important animal, providing meat, milk, skin, and hides. In Egypt, Dyab et al. [4] did not detect CE infection in buffaloes, while Haridy et al. [5] recorded 6.4\% infection rate.

Recently, the taxonomic revisions of Echinococcus illustrated its complexity into a number of species and genotypes exhibiting a marked genetic variability, based on mitochondrial DNA analysis. Studies have identified 10 distinct genotypes (G1-G10) within four species of the Echinococcus granulosus complex [6]. These include E. granulosus sensu lato (G1-G3 cluster), Echinococcus equinus (G4), Echinococcus ortleppi (G5), and Echinococcus canadensis (G6-G10). The genotypes are classified into two sheep strains (G1 and G2), two bovid strains (G3 buffalo and G5 cattle), a horse strain (G4), a camel strain (G6), two pig strains (G7 and G9), and finally two cervid strains (G8 and G10). Moreover, a lion strain, Echinococcus felidis, was reported. These variants are broadly distributed geographically and have a wide range of host specificity.

Reports about the genotypes of CE infecting buffaloes are considerably low due to the scarcity number of countries in which buffaloes can accommodate to living. The majority of studies illustrated the susceptibility of this animal species to the G1-3 cluster [7,8] although cattle strain (G5) was reported in India $[9,10]$. 
Molecular studies on hydatid cyst isolates from the Egyptian animals and human illustrated the presence of G1, G4, G5, and G6, which considered the most prevalent genotype [11-13]. Previously, 2 buffalo samples, obtained from Cairo, were genotyped as G6 (camel strain) [13]. Herein, we examine the slaughtered water buffaloes at Dakahlia province for hydatid cysts to update the CE epidemiology and to clarify if there are genotypes other than G6 infecting water buffaloes from Egypt.

\section{Materials and Methods}

\section{Ethical approval}

This study was conducted after getting approval from both Scientific and Animal Ethics Committees of Faculty of Veterinary Medicine, Mansoura University, Egypt.

\section{Samples collection and DNA isolation}

A 120 water buffaloes slaughtered at Mansoura Abattoir, Dakahlia Province, Egypt, were examined for the presence of hydatid cysts. Cysts were dissected out and washed with phosphate buffer saline (PBS). Cysts fertility was assessed by examining the hydatid fluid and the germinal layer for protoscolices. The germinal layer, as well as the protoscolices, was harvested. Both were washed 3 times in PBS ( $\mathrm{pH} 7.2$ ) and stored at $-20^{\circ} \mathrm{C}$ until used. Total DNA of protoscolices and/or germinal layers was extracted using the NucleoSpin ${ }^{\circledR}$ Tissue kit (Macherey-Nagel, Düren, Germany), according to the manufacturer's instructions.

\section{Molecular analysis}

Two mitochondrial genes were amplified by polymerase chain reaction (PCR): The cytochrome C oxidase subunit $1(\operatorname{cox} 1)$ gene [14] and the nicotinamide adenine dinucleotide hydrogen subunit 1 (nadh1) gene [15]. Primers COI 1 (forward) 50-TTTTTTGGCCATCCTGAGGTTTAT-30 and COI 2 (reverse) 50-TAACGACATAACATAATGAAAATG30 were used to amplify the cox 1 gene by 30 cycles. Each cycle consisted of denaturation at $94^{\circ} \mathrm{C} 30 \mathrm{~s}$, annealing at $55^{\circ} \mathrm{C} 30 \mathrm{~s}$ and elongation at $72^{\circ} \mathrm{C} 30 \mathrm{~s}$ followed by a final extension at $72^{\circ} \mathrm{C} 7 \mathrm{~min}$. Primers NADH 1 (forward) 50-AGTCTCGTAAGGGCCCTAACA-30 and NADH 2 (reverse) 50-CCCGCTGACC AACTCT CTTTC-30 were used to amplify the nadh1 gene by 35 cycles. Each cycle consisted of denaturation at $94^{\circ} \mathrm{C}$ $30 \mathrm{~s}$, annealing at $53^{\circ} \mathrm{C} 30 \mathrm{~s}$, and elongation at $72^{\circ} \mathrm{C}$ $30 \mathrm{~s}$ followed by a final extension at $72^{\circ} \mathrm{C} 7 \mathrm{~min}$. A negative control (without genomic DNA) was included in the study.

PCR amplification was carried out in $35 \mu \mathrm{L}$ final mixture containing $2 \mu \mathrm{L}$ of template DNA, $1 \mu \mathrm{L}$ $(25 \mu \mathrm{M})$ of each primer, $0.7 \mu \mathrm{L}(10 \mathrm{mM})$ deoxynucleotide triphosphate mix, $3.5 \mu \mathrm{L}$ of Taq buffer $(\times 10)$, $0.35 \mu \mathrm{L}$ Taq polymerase (5 Prime Perfect Taq ${ }^{\mathrm{TM}}$ ), and $26.45 \mu \mathrm{L}$ nuclease free water. PCR products were separated on agarose gels (1\%) stained with ethidium bromide (Figure-1). Gel bands were cut out, and
DNA was purified using QIAquick gel extraction kits (Qiagen, Germany) following the manufacturer's instruction. The purified DNA was commercially sequenced in both directions. Genotypes identification and the reference sequences (Tables-1 and 2) were achieved using GenBank with the BLAST system. Bioedit software was used to align the different sequences, while the phylogenetic analysis was initiated using the neighbor-joining method of the software Mega (version 6) with Kimura 2-parameter model.

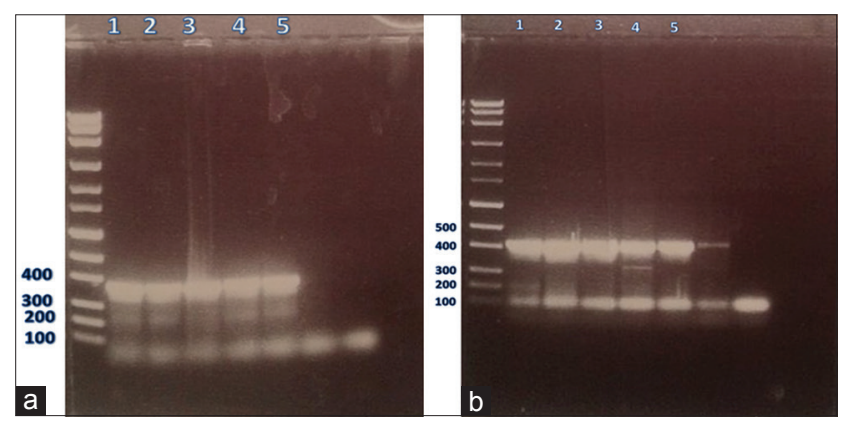

Figure-1: (a-b) Polymerase chain reaction results of cytochrome $\mathrm{C}$ oxidase subunit 1 (a) and nicotinamide adenine dinucleotide hydrogen 1 (b) genes on $1 \%$ agarose gel stained with ethidium bromide. From left to right: DNA marker, four fertile lung cysts (1-4) then one sterile liver cyst (5) followed by caseated lung cyst failed to be amplified and the negative control.

Table-1: Partial cox1 sequences retrieved from Genbank and used in this study.

\begin{tabular}{|c|c|c|c|}
\hline Country & Animal & Accession number & References \\
\hline \multirow[t]{4}{*}{ Egypt } & Sheep & AB921090 & {$[13]$} \\
\hline & Camel & AB921054 & \\
\hline & Camel & AB921055 & \\
\hline & Buffalo & AB921072 & \\
\hline Jordan & Sheep & AB688598 & {$[36]$} \\
\hline \multirow[t]{7}{*}{ Iran } & Goat & KR337824 & Unpublished \\
\hline & Human & JQ250815 & {$[36]$} \\
\hline & Sheep & JQ250816 & \\
\hline & Goat & JQ250807 & \\
\hline & Camel & JQ250814 & \\
\hline & Buffalo & HM130592 & [24] \\
\hline & & HM130597 & \\
\hline \multirow[t]{6}{*}{ China } & Dog & DQ356882 & Unpublished \\
\hline & Sheep & AB688612 & [36] \\
\hline & Human & AB688613 & \\
\hline & & AB688617 & \\
\hline & Cattle & AY389989 & Unpublished \\
\hline & Sheep & AY386210 & Unpublished \\
\hline Tibet plateau & Sheep & KJ628364 & Unpublished \\
\hline \multirow[t]{3}{*}{ Mongolia } & Human & AB893250 & [37] \\
\hline & Sheep & AB787532 & Unpublished \\
\hline & Goat & AB787536 & \\
\hline \multirow[t]{2}{*}{ Nepal } & Buffalo & AB551110 & Unpublished \\
\hline & Pig & AB522647 & Unpublished \\
\hline Portugal & Sheep & HF947595 & [38] \\
\hline \multirow[t]{4}{*}{ Russia } & Human & AB688140 & [39] \\
\hline & Cat & AB622277 & [40] \\
\hline & Human & AB777908 & [41] \\
\hline & Sheep & AB777905 & \\
\hline \multirow[t]{2}{*}{ Peru } & Cattle & AB688620 & [36] \\
\hline & Sheep & AB688621 & \\
\hline
\end{tabular}

$\operatorname{cox} 1=$ Cytochrome $\mathrm{C}$ oxidase subunit 1 
Table-2: Partial nadh1 sequences retrieved from Genbank and used in this study.

\begin{tabular}{|c|c|c|c|}
\hline Country & Animal & $\begin{array}{c}\text { Accession } \\
\text { number }\end{array}$ & References \\
\hline \multirow[t]{4}{*}{ Egypt } & Sheep & AB921125 & [13] \\
\hline & Camel & AB921091 & \\
\hline & Camel & AB921092 & \\
\hline & Buffalo & AB921109 & \\
\hline \multirow[t]{2}{*}{ Tunisia } & Cattle & KT363806 & Unpublished \\
\hline & Cattle & KT005319 & \\
\hline \multirow[t]{3}{*}{ Morocco } & Sheep & EF367308 & Unpublished \\
\hline & Cattle & EF367334 & \\
\hline & Camel & EF367316 & \\
\hline \multirow[t]{4}{*}{ Iran } & Cattle & HM055619 & Unpublished \\
\hline & Sheep & HM055626 & \\
\hline & Camel & GQ357999 & Unpublished \\
\hline & Goat & KJ162553 & Unpublished \\
\hline \multirow[t]{5}{*}{ India } & Buffalo & EF179167 & Unpublished \\
\hline & Sheep & EF179166 & \\
\hline & Buffalo & EF125695 & \\
\hline & Cattle & EF125693 & \\
\hline & Goat & GQ168810 & Unpublished \\
\hline \multirow[t]{3}{*}{ China } & Human & KJ556994 & [42] \\
\hline & Cattle & AY386215 & Unpublished \\
\hline & Sheep & AY572546 & Unpublished \\
\hline Tibetan plateau & Sheep & JX217883 & [43] \\
\hline Argentina & Cattle & KC579441 & [44] \\
\hline \multirow[t]{2}{*}{ Peru } & Cattle & JF946610 & Unpublished \\
\hline & Camel & JF828342 & \\
\hline
\end{tabular}

\section{Results}

Examination of 120 slaughtered water buffaloes in Mansoura Abattoir, Dakahlia province, Egypt, demonstrated the presence of hydatid cysts in 5 carcasses $(4.2 \%)$. One infected animal harbored 14 sterile cysts in its liver (Figure-2), while the lung is the affected tissue in four animals (two of them had single fertile cyst infection, one had 2 fertile cysts, and the last one had 9 caseated sterile cysts). Collectively, $4(14.8 \%)$ out of 27 collected cysts were fertile.

\section{Genotype identification and sequence analysis}

Clear and readable nucleotide sequences were revealed from the 5 examined cysts (four fertile lung cysts and one sterile liver cyst). Alignment of the 5 samples with each other indicated that all of them were belonged to the same haplotype, and they were typed under the E. granulosus G1 genotype (common sheep strain).

At the level of cox1 gene, single nucleotide substitution (C257T) was noted by alignment of this study haplotype and the reference sequence M84661 (the first described G1 by Bowles et al. [14]) (Figure-3). Nevertheless, complete identity was found with a number of G1 isolates from different countries and host species like sheep from Tibet (KJ628364), goats from Iran (KR337824), and human from Mongolia (AB893250).

Concerning the nadh1 gene, a unique mutational site (A132G) was noted in our haplotype when aligned with different reference sequences (Figure-4), rather than another nucleotide substitution (C282T)

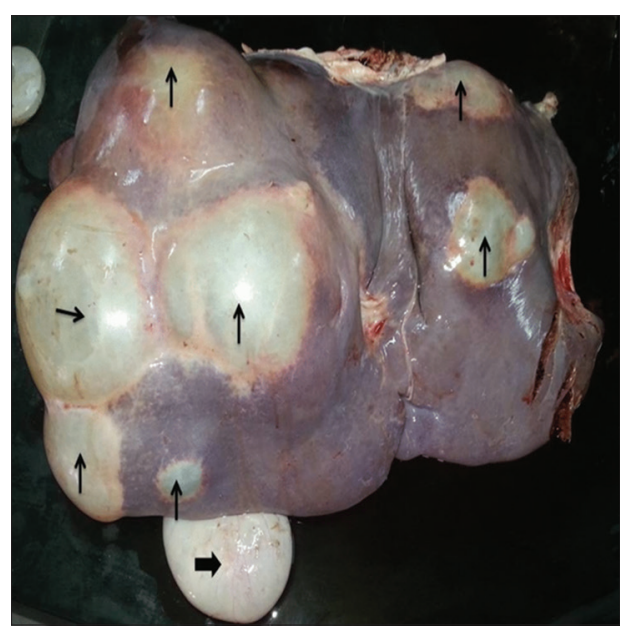

Figure-2: A buffalo's liver infected with multi-localized large and medium sized hydatid cysts (arrow). The big arrow refers to the gall bladder.

with AJ237632 (The first described G1 by Bowles and McManus [15]). Moreover, 99\% homology was recorded with the reported G1 genotype from each of Tunisia (KT363806), Morocco (EF367308), Iran (GQ357999), and India (EF179167).

\section{Phylogenetic analysis}

Using the G5 and G6 genotypes from the Egyptian camels and buffaloes, respectively, as an out group, the neighbor-joining phylogenetic trees indicated the clustering of our G1 haplotype within the other G1 haplotypes from variable host species in different geographical regions (Figures-5 and 6). Despite the nadh1 illustrated the separation of our haplotype in a unique branch within the same G1 clade (Figure-6).

\section{Discussion}

$\mathrm{CE}$ is an important economic and life-threatening zoonotic disease. In view of its economic importance, we aimed to update the knowledge about CE from water buffaloes slaughtered in Egypt.

In total, the examined 120 buffalo carcasses revealed $4.2 \%$ infection with hydatid cysts. The previous report from the same district (Mansoura) recorded $6.4 \%$ infection rate [5]. However, three reports from Cairo [16] and Upper Egypt [4,17] did not observe CE infection in the Egyptian buffaloes. This indicates the endemicity of CE in buffaloes at Mansoura, Dakahlia province. Diversified prevalences were reported from different countries such as $42 \%$ in Greece [18], 8.7\% in Italy [19], 3.81\% in India [10], 9\% in Iran [20], and $7.19 \%$ in Pakistan [21].

Furthermore, lungs appeared to be the predilection site for CE in buffaloes $(80 \%$ out of the examined animals), coinciding with results from studies conducted in Turkey [8] and Italy [22].

On the other hand, the fertility rate of the harvested cysts was considerably low (14.8\%). Our molecular results indicated the homogeneity of those cysts with G1 genotype (common sheep strain). Furthermore, the previous reports discussed the low fertility rate of 


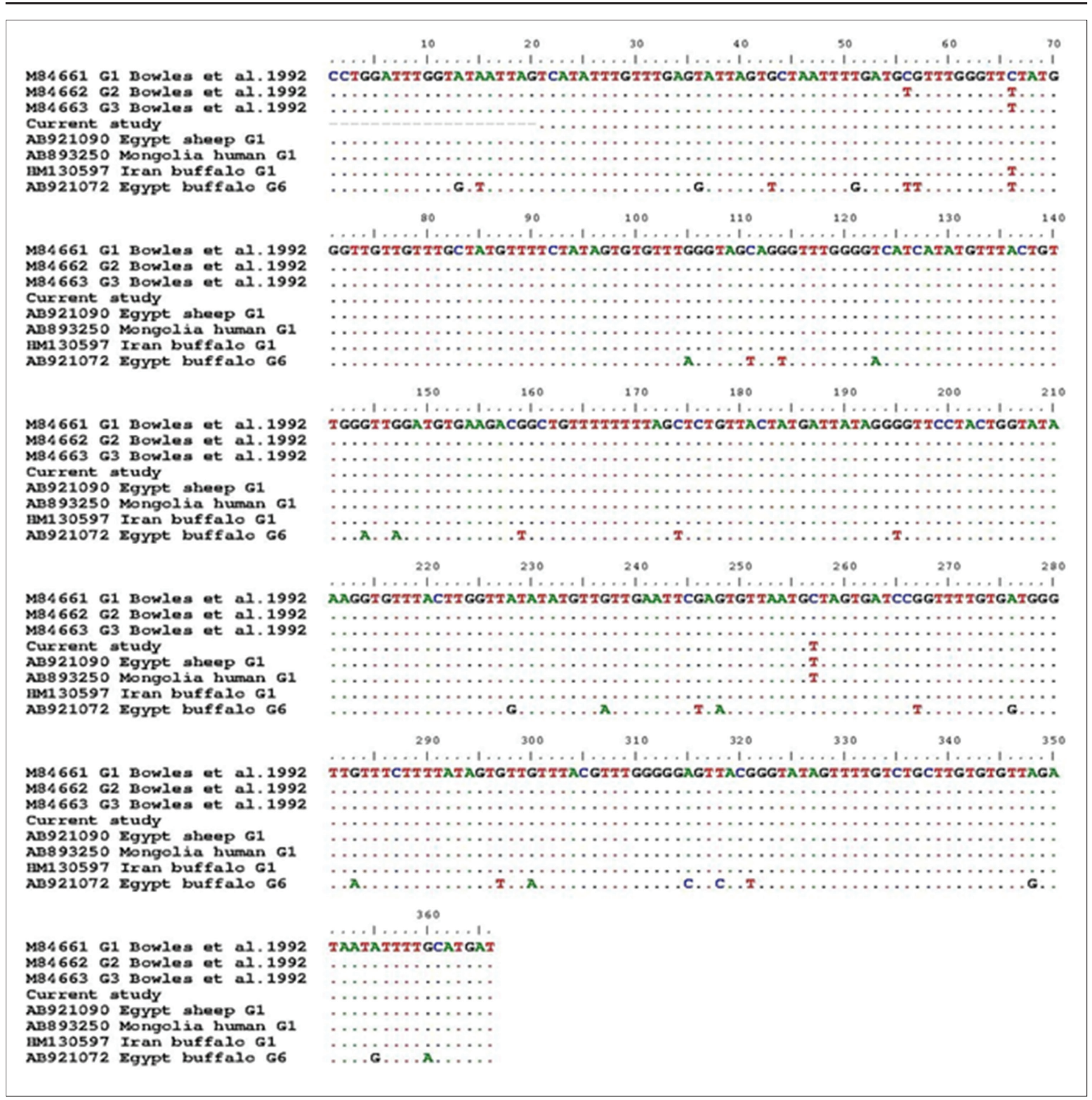

Figure-3: Alignment of partial cytochrome $\mathrm{C}$ oxidase subunit 1 sequences of the buffaloes isolate in the present work with variable reported haplotypes on Genbank. This figure shows the complete identity between our G1 haplotype with those reported from the Egyptian sheep (AB921090).

hydatid cysts of buffaloes $(7.3 \%)$ and their relation to the G1 $[18,20]$. While in Pakistan, where the G3 (buffalo strain) was the prevalent genotype, the fertility rate was high $(84.3 \%)$ [21]. Therefore, this could be explained by the low adaptation of buffaloes to the common sheep strain which increases the tendency of sterile cysts formation [23]. Consequently, our results assumed the reduced role played by buffaloes in maintaining the Echinococcus life cycle in this geographical area.

The analyzed sequences of the 5 hydatid cyst isolates in the present work indicated the infection of the Egyptian buffaloes with the G1 genotype. Previously, 2 samples from the Egyptian buffaloes were characterized as G6 which not described before from buffaloes worldwide [13]. Considering reports from buffalo rearing countries (Table-3), G1 was the widely dispersed genotype in Iran [24]; India [25], Pakistan [26], Italy [27], Turkey [8], and Greece [18]. Although, G3 (buffalo strain) and G5 (cattle strain) were recorded but in few cases $[7,21,25,28]$. This is the first report about the existence of the G1 genotype in buffaloes from Egypt.

The alignment results of the partial cox 1 sections (Figure-3) showed the complete matching of the G1 isolates from buffaloes in this work with that of sheep (AB921090) and camels (AB921054) from Egypt, which represented phylogenetically by 


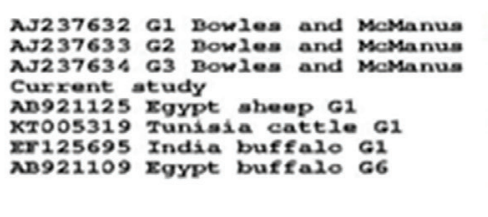

AJ237632 G1 Dowles and McManus AJ237633 G2 Dowles and McManus
AJ237634 G3 Bowles and McManus Curxent atudy ND921125 Egypt sheep 61 KT005319 Tuniaia cattie G1 xr125695 India buffalo G1
N0921109 Egypt buffalo 66

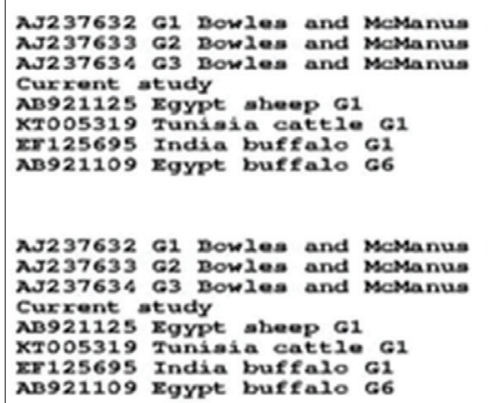
XP125695 India buffalo G1

\section{AJ237632 G1 Dowles and MCManua}

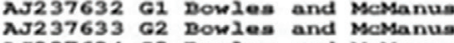
AN2 37633 G2 Dowles and McManus
AJ2 37634 G3 Dowdes and McManus Cuxxent atudy AB921125 Egypt sheep 61 Kro05319 Tuniaia cattle G1 EF 125695 India buffalo G1 AB921109 Egypt buffalo G6

AN237632 G1 Dowles and McManus AN237633 G2 Dowles and McManus Curxent atudy ND921125 Egypt sheep G1 Xro05319 Tuniaia cattle G1 EF125695 India buffalo G1 AJ237632 G1 Dowles and McManus
AN237633 G2 Bowles and McManus AJ237634 G3 Dowdes and McManu. Current study AD921125 Egypt sheep 61 Kroos319 Tuniaia cattie 61 EF125695 India buffalo G1

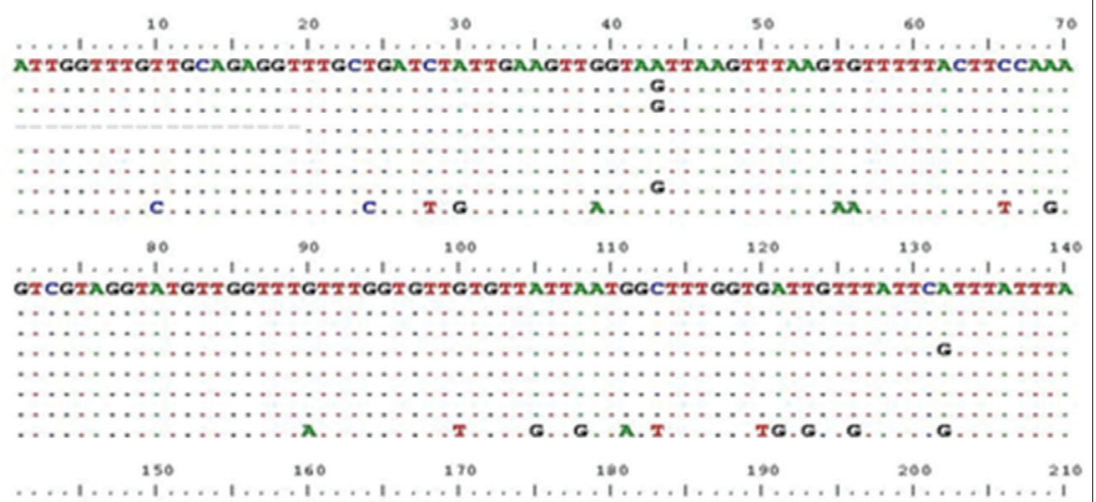

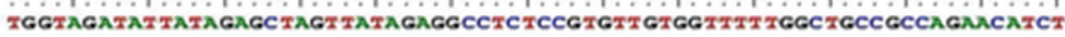

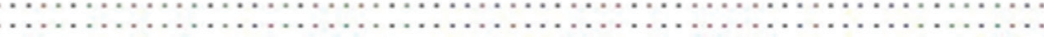

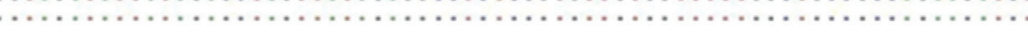

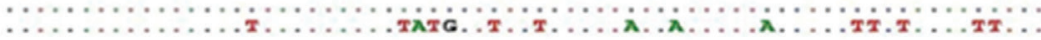

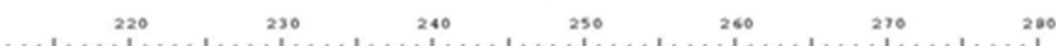

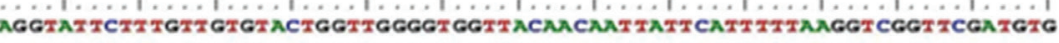

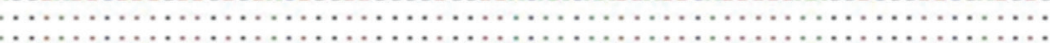

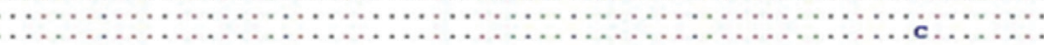
… $\begin{array}{llllll}280 & 300 & 320 & 320 & 330 & 340\end{array}$

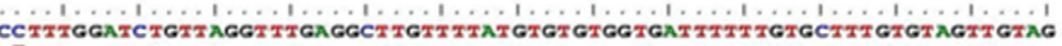

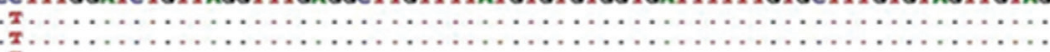

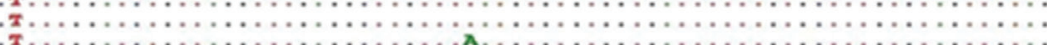

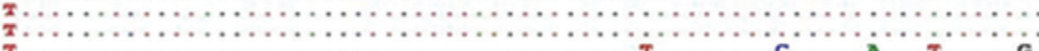

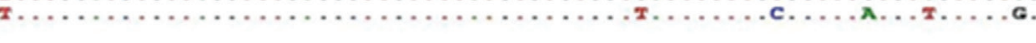

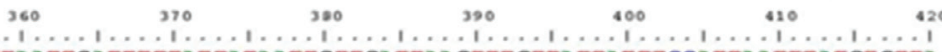

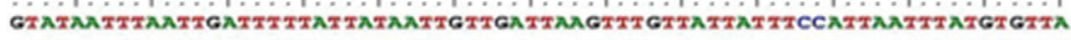

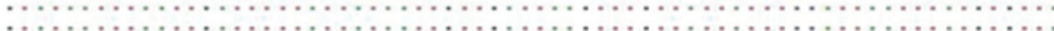


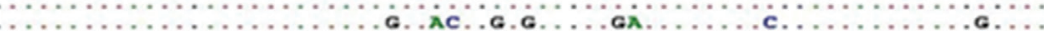

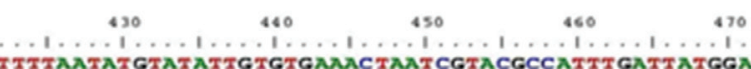

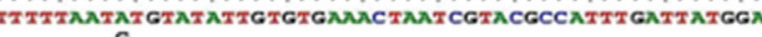
G.

c.

Figure-4: Alignment of partial nicotinamide adenine dinucleotide hydrogen 1 sequences of the buffaloes isolate in the present work with variable reported haplotypes on Genbank. A singleton G1 haplotype was noted in the present work with a unique mutational site (A132G).

Table-3: Genotypes distribution of hydatid cyst isolates from water buffaloes within different buffaloes rearing countries.

\begin{tabular}{|c|c|c|c|c|}
\hline Country & No. & Genetic marker & Genotype & References \\
\hline Egypt & 2 & cox1, nadh1, actinII & G6 & [13] \\
\hline Turkey & 9 & $\operatorname{cox} 1$ & G1 (7), G2 (2) & [8] \\
\hline Greece & 24 & cox1, nadh1 & G1-G3 & [18] \\
\hline \multirow[t]{4}{*}{ Italy } & 48 & $\operatorname{cox} 1$ & G1 (33), (G2) (15) & [34] \\
\hline & 58 & $\operatorname{cox} 1$ & $\mathrm{G} 1$ (35), G2 (8), G3 (15) & [27] \\
\hline & 5 & $\operatorname{cox} 1$, nadh 1 & $\mathrm{G} 1(2), \mathrm{G} 2(1), \mathrm{G} 3(2)$ & {$[7]$} \\
\hline & 11 & $12 \mathrm{~S}$ rRNA & $\mathrm{G} 1(3), \mathrm{G} 2(8)$ & [22] \\
\hline \multirow[t]{3}{*}{ Iran } & 1 & $\operatorname{cox} 1$ & G3 & [28] \\
\hline & 25 & $\operatorname{cox} 1$ & G1 (23), G2 (2) & [24] \\
\hline & 4 & cox1, nadh1, Atp6, $12 \mathrm{~S}$ rRNA & G1 & [29] \\
\hline \multirow[t]{4}{*}{ India } & 6 & $\operatorname{cox} 1$, nadh1, ITS1 & G2 & [9] \\
\hline & 7 & atp6 and nad2 & $\mathrm{G} 1(6) ; \mathrm{G} 5(1)$ & [25] \\
\hline & 13 & $\operatorname{cox} 1$ & G1 (3), G3 (8), G5 (2) & [10] \\
\hline & 1 & $\operatorname{cox} 1$ & G3 & [35] \\
\hline \multirow[t]{2}{*}{ Pakistan } & 4 & $\operatorname{cox} 1$ & G3 & [21] \\
\hline & 129 & 12S rRNA & G1 (76) & {$[26]$} \\
\hline
\end{tabular}

Cox1 = Cytochrome $\mathrm{C}$ oxidase subunit 1, nadh $1=$ Nicotinamide adenine dinucleotide hydrogen subunit 1 


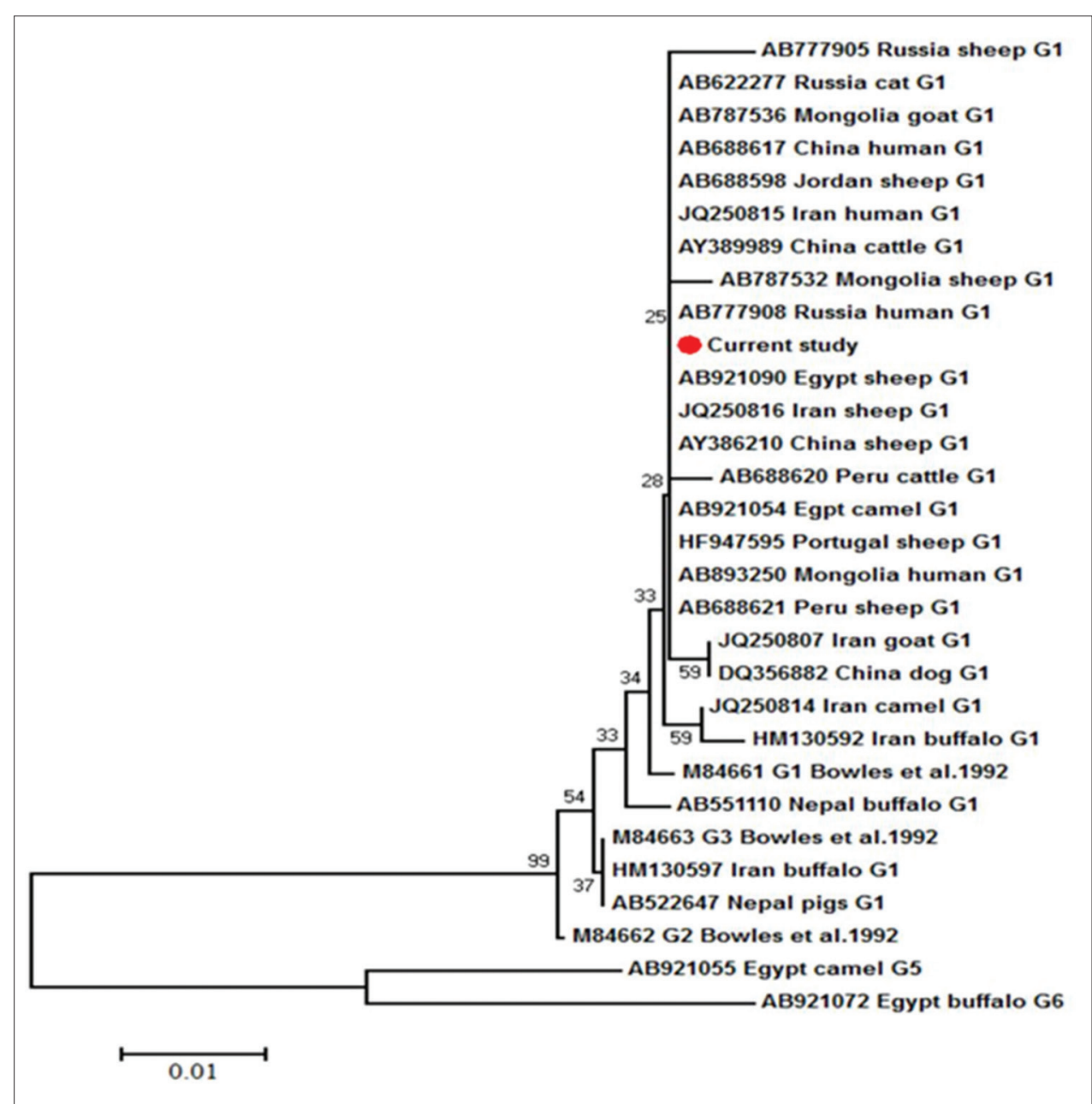

Figure-5: Neighbor-Joining phylogenetic tree of G1 genotype partial cytochrome C oxidase subunit 1 sections from different hosts and geographical regions. G5 and G6 genotypes were used as an out group. The bootstrap analysis was conducted using 1000 replicates. Scale bar indicates the proportion of sites changing along each branch.

their sharing of the same branch. On the contrary, our isolates evoked a singleton G1 haplotype, at the level of nadh1 partial sections (Figure-4), which not previously reported from Egypt and worldwide. This haplotype was clustered in a separate branch and nearer to the G1 haplotype from the Indian cattle (EF125693) and buffaloes (EF179167), which assuming the introduction of this haplotype to Egypt through the imported cattle and buffaloes meat from India. Moreover, the previous results illustrated the more usefulness of nadh1 than cox1 in studying Echinococcus haplotypes diversity [29], although Bowles and McManus [15] found identical sequences of G2 and G3 for nadh1 gene in the same tested samples with cox1which showed 2 mutational sites between both genotypes (Figure-4).

Little is known about the genotypes of Echinococcus from the Egyptian animals and human. Studies illustrated the wide domination of the G6 (camel strain), which favors the role the camel-dog cycle in the transmission of echinococcosis $[11,13,30,31]$. Here, we have notice that all the collected samples in these studies were originated from the same area (Cairo and Qalubiya provinces), which considered the main localities in Egypt for importing camels and consuming their meats. Furthermore, G1 genotype (common sheep strain) was described in one camel as well as 4 sheep samples [13], and in one out of 31 human samples [11]. In addition, Abd El Baki et al. [32] stated that $80 \%$ of human and camel isolates were belonged to G1. From the zoonotic point of view, it is well known that the majority of human cysts were typed under the G1 and its variants $[1,18,33]$, and thus emphasis the great role of the sheep-dog cycle in echinococcosis transmission for different reasons, like the wide use of dogs with sheep flocks for protection, the commonness of the out-abattoir sheep slaughter in the rural communities specially in the ceremonies like Al-Adhua feast in Muslims countries and the unsatisfactory offal disposal which enable dogs to access easily the hydatid cysts. This assumption is clearly evident in our results which illustrated the commonness of G1 genotype in buffaloes from Dakahkia province, Egypt.

\section{Conclusion}

In spite of the low infection and fertility rates of buffalo, hydatid cysts recorded in this study, the mission, even a weak, of this animal for keeping G1 genotype life cycle is still important. 


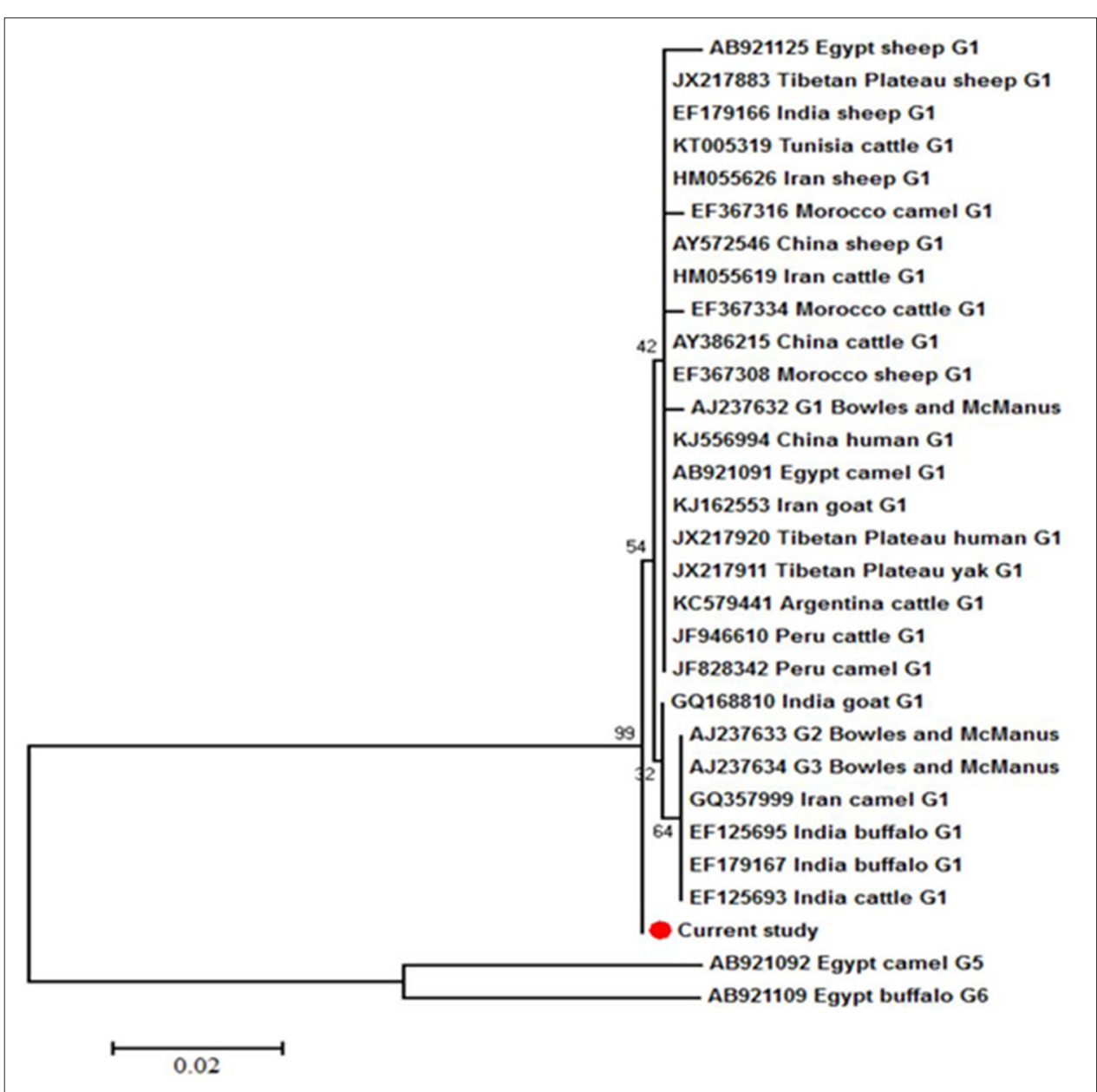

Figure-6: Neighbor-Joining phylogenetic tree of G1 genotype partial nicotinamide adenine dinucleotide hydrogen 1 sections from different hosts and geographical regions. G5 and G6 genotypes were used as an out group. The bootstrap analysis was conducted using 1000 replicates. Scale bar indicates the proportion of sites changing along each branch.

\section{Authors' Contributions}

Study design, samples collection, laboratory work, and the manuscript writing was done by IA. IA has read and approved the final manuscript.

\section{Acknowledgment}

The author wishes to thank Dr. Mahmoud Al-Embaby, Veterinarian Abattoir Staff, for his continuous help in collecting the samples.

\section{Competing Interests} interests.

The author declares that they have no competing

\section{References}

1. McManus, D.P., Zhang, W., Li, J. and Bartley, P.B. (2003) Echinococcosis. Lancet, 362: 1295-1304.

2. Moro, P. and Schantz, P.M. (2009) Echinococcosis: A review. Int. J. Infect. Dis., 13: 125-133.

3. Ahmed, A.M., Ismail, S.A.S. and Dessouki, A.A. (2013) Pathological lesions survey and economic loss for male cattle slaughtered at Ismailia abattoir. Int. Food Res. J., 20(2): 857-863.

4. Dyab, K.A., Hassanein, R., Hussein, A.A., Metwally, S.E. and Gad, H.M. (2005) Hydatidosis among man and animals in Assiut and Aswan governorates. J. Egypt. Soc. Parasitol., 35: 157-166.
5. Haridy, F.M., Ibrahim, B.B., Elshazly, A.M., Awad, S.E., Sultan, D.M., El-Sherbini, G.T. and Morsy, T.A. (2006) Hydatidosis granulosus in Egyptian slaughtered animals in the years 2000-2005. J. Egypt. Soc. Parasitol., 36(3): 1087-1100.

6. Nakao, M., Lavikanien, A., Yanagida, T. and Ito, A. (2013) Phylogenetic systematic of the genus Echinococcus (Cestods: Taeniidae). Int. J. Parasitol., 43: 1017-1029.

7. Casulli, A., Manfredi, M.T., Rosa, G.L., Di Cerbo, A.R., Genchi, C. and Pozio, E. (2008) Echinococcus ortleppi and Echinococcus granulosus G1, G2 and G3 genotypes in Italian bovines. Vet. Parasitol., 155: 168-172.

8. Beyhan, Y.E. and Umur, S.I. (2011) Molecular characterization and prevalence of cystic echinococcosis in slaughtered water buffaloes in Turkey. Vet. Parasitol., 181: 174-179.

9. Bhattacharya, D., Bera, A.K., Bera, B.C., Maity, A. and Das, S.K. (2007) Genotypic characterisation of Indian cattle, buffalo and sheep isolates of Echinococcus granulosus. Vet. Parasitol., 143: 371-374.

10. Pednekar, R.P., Gatne, M.L., Thompson, R.C. and Traub, R.J. (2009) Molecular and morphological characterization of Echinococcus from food producing animals in India. Vet. Parasitol., 165: 58-65.

11. Aaty, H.E.A., Abdel-Hameed, D.M., Alam-Eldin, Y.H., El-Shennawy, S.F., Aminou, H.A., Makled, S.S. and Darweesh, S.K. (2012) Molecular genotyping of Echinococcus granulosus in animal and human isolates from Egypt. Acta Trop., 121(2): 125-128.

12. Aboelhadid, S.M., El-Dakhly, K.M., Yanai, T., Fukushi, H. 
and Hassanin, K.M. (2012) Molecular characterization of Echinococcus granulosus in Egyptian donkeys. Vet. Parasitol., 193: 292-296.

13. Amer, S., Helal, I.B., Kamau, E., Feng, Y. and Xiao, L. (2015) Molecular characterization of Echinococcus granulosus senso lato from farm animals in Egypt. PLoS One, 10(3): 1-12.

14. Bowles, J., Blair, D. and McManus, D.P. (1992) Genetic variants within the genus Echinococcus identified by mitochondrial DNA sequencing. Mol. Biochem. Parasitol., 54(2): 165-173.

15. Bowles, J. and McManus, D.P. (1993) NADH dehydrogenase 1 gene sequences compared for species and strains of the genus Echinococcus. Int. J. Parasitol., 23(7): 969-972.

16. Rahman, M.S., Sokkar, S.M. and Dahab, S. (1992) Comparative studies on hydatidosis in farm animals in Egypt. Dtsch. Tierarztl. Wochenschr., 99: 438-440.

17. Omar, M., Sultan, K., Haridy, M. and Omran, A. (2013) Prevalence of cystic echinococcosis in slaughtered ruminants in different abattoirs, Upper Egypt. Am. J. Anim. Vet. Sci., 8(3): 117-121.

18. Chaligiannis, I., Maillard, S., Boubaker, G., Spiliotis, M., Saratsis, A., Gottstein, B. and Sotiraki, S. (2015) Echinococcus granulosus infection dynamics in livestock of Greece. Acta Trop., 150: 64-70.

19. Cringoli, G., Veneziano, V., Rinaldi, L., Capuano, F. and Garippa, G. (2006) Cystic echinococcosis in water buffaloes from the Campania region of southern Italy. Vet. Res. Commun., 30(1): 245-248.

20. Pour, A.A., Hosseini, S.H. and Shayan, P. (2012) The prevalence and fertility of hydatid cysts in buffaloes from Iran. J. Helminthol., 86(3): 373-377.

21. Latif, A.A., Tanveer, A., Maqbool, A., Siddiqi, N., Kyaw-Tanner, M. and Traub, R.J. (2010) Morphological and molecular characterization of Echinococcus granulosus in livestock and humans in Punjab, Pakistan. Vet. Parasitol., 170: 44-49.

22. Rinaldi, L., Maurelli, M.P., Capuano, F., Perugini, A.G., Veneziano, V. and Cringoli, S. (2008) Molecular update on cystic echinococcosis in cattle and buffaloes of Southern Italy. Zoonoses Public Health, 55: 119-123.

23. Balbinotti, H., Santos, G.B., Badaraco, J., Arend, A.C., Graichen, S., Haag, K.L. and Zaha, A. (2012) Echinococcus ortleppi (G5) and Echinococcus granulosus senso stricto (G1) loads from cattle in Southern Brazil. Vet. Parasitol., 188: 255-260.

24. Pour, A.A., Hosseini, S.H. and Shayan, P. (2011) Comparative genotyping of Echinococcus granulosus infecting buffalo in Iran using cox 1 gene. Parasitol. Res., 108: 1229-1234.

25. Gudewar, J., Pan, D., Bera, A.K., Das, S.K., Konar, A., Rao, J.R., Tiwari, A.K. and Bhattacharya, D. (2009) Molecular characterization of Echinococcus granulosus of Indian animal isolates on the basis of nuclear and mitochondrial genotype. Mol. Biol. Rep., 36(6): 1381-1385.

26. Shahzad, W., Abbas, A., Munir, R., Khan, M.S., Avais, M., Ahmad, J., Rana, M.Y. and Mehmood, F. (2014) A PCR analysis of prevalence of Echinococcus granulosus genotype G1 in small and large ruminants in three districts of Punjab, Pakistan. Pak. J. Zool., 46(6): 1541-1544.

27. Capuano, F., Maurelli, M.P., Rinaldi, L., Perugini, A.G., Veneziano, V., Musella, V. and Cringoli, G. (2007) Cystic echinococcosis in water buffaloes (Bubalus bubalis). Ital. J. Anim. Sci., 6 Suppl 2: 915-916.

28. Babazadeh, M., Sharifiyazdi, H., Moazeni, M., Gorjipour, S. and Heidari, M. (2015) Molecular characterization of a new microvariant of the G3 genotype for Echinococcus granulosus in water buffalo in Iran. Vet. Res. Forum, 6(1): 83-87.

29. Nejad, M.R., Taghipour, N., Nochi, Z., Mojarad, E.N., Mohebbi, S.R., Harandi, M.F. and Zali, M.R. (2002)
Molecular identification of animal isolates of Echinococcus granulosus from Iran using four mitochondrial genes. J. Helminthol., 86(4): 485-492.

30. Khalifa, N.O., Khater, H.F., Fahmy, H.A., Radwan, M.E.I. and Afif, J.S.A. (2014) Genotyping and phylogenetic analysis of cystic echinococcosis isolated from camels and humans in Egypt. Am. J. Epidemiol. Infect. Dis., 2(3): 74-82.

31. Abdel-Aziz, A.R. and El-Meghanawy, R.A. (2016) Molecular characterization of hydatid cyst from Egyptian one humped camels (Camelus dromedaries). PSM Vet. Res., 01(1): 13-16.

32. Abd El Baki, M.H., El Missiry, A.M., Abd El Aaty, H.E., Mohamad, A.A. and Aminou, H.A. (2009) Detection of G1 genotype of human cystic echinococcosis in Egypt. J. Egypt. Soc. Parasitol., 39(3): 711-721.

33. Casulli, A., Sreter, T.I., Chitimia, L., Kirkova, Z., La Rosa, G. and Pozio, E. (2012) Genetic variability of Echinococcus granulosus sensu stricto in Europe inferred by mitochondrial DNA sequences. Infect. Genet. Evol., 12: 377-383.

34. Capuano, F., Rinaldi, L., Maurelli, M.P., Perugini, A.G., Veneziano, V., Garippa, G., Genchi, C., Musella, V. and Cringoli, G. (2006) Cystic echinococcosis in water buffaloes: Epidemiological survey and molecular evidence of ovine (G1) and buffalo (G3) strains. Vet. Parasitol., 137(3-4): 262-268.

35. Singh, B.B., Sharma, J.K., Ghatak, S., Sharma, R., Bal, M.S., Tuli, A. and Gill, J.P. (2012) Molecular epidemiology of echinococcosis from food producing animals in north India. Vet. Parasitol., 186: 503-506

36. Yanagida, T., Mohammadzadeh, T., Kamhawi, S., Nakao, M., Sadjjadi, S.M., Hijjawi, N., Abdel-Hafez, S.K., Sako, Y., Okamoto, M. and Ito, A. (2012) Genetic polymorphisms of Echinococcus granulosus sensu stricto in the middle East. Parasitol. Int., 61(4): 599-603.

37. Ito, A., Dorjsuren, T., Davaasuren, A., Yanagida, T., Sako, Y., Nakaya, K., Nakao, M., Bat-Ochir, O.E., Ayushkhuu, T., Bazarragchaa, N., Gonchigsengee, N., Li, T., Agvaandaram, G., Davaajav, A., Boldbaatar, C. and Chuluunbaatar, G. (2014) Cystic echinococcoses in Mongolia: Molecular identification, serology and risk factors. PLoS Negl. Trop. Dis., 8(6): e2937.

38. Beato, S., Parreira, R., Roque, C., Goncalves, M., Silva, L., Maurelli, M.P., Cringoli, G. and Gracio, M.A. (2013) Echinococcus granulosus in Portugal: The first report of the G7 genotype in cattle. Vet. Parasitol., 198(1-2): 235-239.

39. Konyaev, S.V., Yanagida, T., Ingovatova, G.M., Shoikhet, Y.N., Nakao, M., Sako, Y., Bondarev, A.Y. and Ito, A. (2012a) Molecular identification of human echinococcosis in the Altai region of Russia. Parasitol. Int., 61(4): 711-714.

40. Konyaev, S.V., Yanagida, T., Ivanov, M.V., Ruppel, V.V., Sako, Y., Nakao, M. and Ito, A. (2012b) The first report on cystic echinococcosis in a cat caused by Echinococcus granulosus sensu stricto (G1). J. Helminthol., 86(4): 391-394.

41. Konyaev, S.V., Yanagida, T., Nakao, M., Ingovatova, G.M., Shoykhet, Y.N., Bondarev, A.Y., Odnokurtsev, V.A., Loskutova, K.S., Lukmanova, G.I., Dokuchaev, N.E., Spiridonov, S., Alshinecky, M.V., Sivkova, T.N., Andreyanov, O.N., Abramov, S.A., Krivopalov, A.V., Karpenko, S.V., Lopatina, N.V., Dupal, T.A., Sako, Y. and Ito, A. (2013) Genetic diversity of Echinococcus spp. in Russia. Parasitology, 140(13): 1637-1647.

42. Zhang, T., Yang, D., Zeng, Z., Zhao, W., Liu, A., Piao, D., Jiang, T., Cao, J., Shen, Y., Liu, H. and Zhang, W. (2014) Genetic characterization of human-derived hydatid cysts of Echinococcus granulosus sensu lato in Heilongjiang Province and the first report of G7 genotype of E. canadensis in humans in China. PLoS One, 9(10): e109059.

43. Yan, N., Nie, H.M., Jiang, Z.R., Yang, A.G., Deng, S.J., 
Guo, L., Yu, H., Yan, Y.B., Tsering, D., Kong, W.S., Wang, N., Wang, J.H., Xie, Y., Fu, Y., Yang, D.Y., Wang, S.X., Gu, X.B., Peng, X.R. and Yang, G.Y. (2013) Genetic variability of Echinococcus granulosus from the Tibetan plateau inferred by mitochondrial DNA sequences. Vet. Parasitol., 196(1-2): 179-183.
44. Andresiuk, M.V., Gordo, F.P., Saarma, M., Elissondo, M.C., Taraborelli, A., Casalongue, C., Denegri, G. and Saarma, U. (2013) Echinococcus granulosus genotype G1 dominated in cattle and sheep during 2003-2006 in Buenos Aires province, an endemic area for cystic echinococcosis in Argentina. Acta Trop., 127(2): 136-142.

$* * * * * * * *$ 